\title{
13 \\ AS PARTICULARIDADES DO ESTADO NA FORMAÇÃO SOCIAL BRASILEIRA: A REITERAÇÃO DA VIA REPRESSIVA DE CONTENÇÃO DAS REIVINDICAÇÕES POPULARES
}

Douglas Ribeiro Barboza

Caio C. Andrade

\section{Introdução}

O desfecho político derivado da complexa conjuntura que envolve a experiência petista de governos de conciliação de classe, o golpe de 2016 e a ascensão do governo Bolsonaro, cimentou um conjunto de transformações estruturais que fez emergir significativas determinações na composição das forças sociais em luta no cenário brasileiro. 0 novo momento de renovação/restauração possui um nível de eficiência no plano político e ideológico que foi capaz de conformar importantes mecanismos norteadores de subalternidade política, os quais, a partir de uma forma particular de articulação entre coerção e consenso, inseriram o conjunto das classes subalternas no processo de instauração de uma nova fase de hegemonia do capital.

"Modernizando" e reestruturando o modus operandi dos regimes repressivos e inconstitucionais, a contrapartida à atual acentuação da superexploração da força de trabalho e agudização das expressões da questão social é o bloqueio ou a eliminação de toda a luta política, onde qualquer medida das agências da sociedade que expressem as vontades coletivas e projetos societários alternativos passa a ser acusada de antiquada, ineficiente, subversiva e comunista. Os traços elitistas e antipopulares da transformação política e da modernização econômica, e a necessidade de restrição da participação do poder político às forças populares são elementos que (em maior ou menor grau) sempre estiveram presentes na constituição da nossa formação histórica, como parte constituinte das diferentes formas de expressão dos processos que nos conduziram às especificidades da nossa "via não clássica" de revolução burguesa".

\footnotetext{
${ }^{*}$ DOI- 10.29388/978-65-86678-42-0-0-f.395-332

${ }^{1}$ Ou seja, processos que não seguiram as formas de transição ocorridas nas revoluções inglesas do século XVII ou da Grande Revolução Francesa do século XVIII.
} 
No âmbito da tradição marxista, Lenin e Gramsci nos forneceram importantes elementos para a compreensão dos processos de transição "não clássica" para o capitalismo. A noção lenineana de "via prussiana" (LENIN, 1980) serve sobretudo para definir, nos processos de transição para o capitalismo, o modo de adequar a estrutura agrária às necessidades do capital. Na nova ordem fundada pela via prussiana, a antiga grande propriedade rural pré-capitalista não é aniquilada, mas sim vai se transformando gradativamente em empresa capitalista agrária, conservando sua grande dimensão, e mantendo formas de trabalho fundadas na coerção extra-econômica de extração do excedente produzido, através de vínculos de dependência e subordinação, que se realizam desde a violência aberta até a intromissão na vida privada do trabalhador rural. Coutinho (2005) ressalta a evidência de que esse processo

[...] permite a conservação (ou mesmo o fortalecimento) do poder político do velho tipo de proprietário rural, que continua a ocupar postos privilegiados no aparelho de Estado da nova ordem capitalista (Ibidem, p. 45).

A noção de "revolução passiva" é utilizada por Gramsci (2002) com a perspectiva de determinar processos sociais e políticos de transformação para a "modernidade capitalista" promovidos "pelo alto", em que a conciliação entre diferentes frações das classes dominantes consegue garantir a firme manutenção do poder em suas mãos mantendo assim as classes trabalhadoras em sua condição de subalternidade. Esse processo implica sempre dois momentos: o da "restauração" (pois se trata sempre de uma reação à possibilidade de uma transformação efetiva e radical proveniente "de baixo para cima", conservando assim importantes elementos sociais, políticos e econômicos da velha ordem); e o da "renovação" (pois, na medida em que necessita realizar modificações efetivas e operar mudanças necessárias à modernização, muitas demandas populares são assimiladas "pelo alto" e postas em prática pelas velhas camadas dominantes). Gramsci indica duas causas-efeitos da "revolução passiva": 1) o principal instrumento de transformação "pelo alto" é o Estado, e o seu fortalecimento em detrimento da sociedade civil revela, de forma concreta, o predomínio das formas ditatoriais de supremacia em detrimento das formas hegemônicas; 2) a prática do transformismo como modalidade de desenvolvimento histórico que implica a cooptação ou assimilação pelo bloco de poder das frações rivais das pró- 
prias classes dominantes ou até mesmo de setores das classes subalternas. (COUTINHO, 1999, p. 198).

Tais noções e conceitos se revelaram de utilidade inestimável para contribuir na especificação e análise do caminho brasileiro para o capitalismo e sua consolidação. Nosso passado colonial - de um país exportador fundado no latifúndio de monocultura extensiva, assentado no compromisso entre o instituto da escravidão, o liberalismo econômico e um forte conservantismo sociocultural e político, traduzido no mandonismo oligárquico (PRADO JR., 2000; IANNI, 2004; SCHWARZ, 2000) - e a condição subordinada e dependente de nossa inserção no modo de produção capitalista e à ordem imperialista (FERNANDES, 1976, 1981a) teriam imposto uma forma política que implicaria a determinação "pelo alto" das condições fundamentais de desenvolvimento e garantia das relações sociais de produção burguesas (IASI, 2019a ; COUTINHO, 2005).

A possibilidade de ruptura radical com o passado foi anulada perante a efetivação da opção de conservação dos traços essenciais das relações sociais "arcaicas" e a dependência ampliada do capital internacional. Assim, em vez de ser resultado de movimentos populares, a modalidade antijacobina de transição ao capitalismo no Brasil foi um processo realizado graças ao deslocamento da função hegemônica entre as diferentes frações das classes dominantes, à utilização permanente dos aparelhos repressivos e de intervenção econômica do Estado para garantir os interesses destas, e à eliminação das forças populares da possibilidade de participação no direcionamento da vida social e nos processos e centros políticos decisórios.

A questão agrária é decisiva para a compreensão das formas históricas assumidas pelo Estado ante a permanente presença dos interesses vinculados à propriedade territorial na composição política do poder, interferindo nas grandes transformações operadas na vida da nação. Nossa "via não clássica" de transformação capitalista teve como uma de suas protagonistas a velha oligarquia agrária - dos proprietários de terras e de escravos - a qual se modernizou e se recompôs economicamente e reconstruiu alianças para garantir a sua manutenção no bloco de poder, influenciando de forma decisiva os pilares conservadores da dominação burguesa. A debilidade histórica dos poucos momentos de construção democrática (mesmo que "dentro da ordem") teve como complemento a constante vitória ou predomínio do Estado forte, do caráter autocrático, do regime de exceção e da ditadura civil ou militar (IANNI, 1984). Conforme nos esclarece Iamamoto (2006), a constante dessa trajetória tem sido a permanente exclusão dos trabalhadores urbanos e rurais das decisões do Estado e do bloco do poder, 
sujeitos a repressão centralizadora do Estado e ao arbítrio do poder privado dos chefes políticos locais e regionais. Ou seja, na história da sociedade brasileira, a socialização da política sempre foi um processo inconcluso (NETTO, 2005).

Considerando todos estes aspectos, mostra-se a necessidade urgente de recuperarmos as características e elementos estruturantes de nosso passado como forma de ampliar a capacidade de análise do presente, objetivando melhor explicá-lo. E é justamente a partir dessa necessidade que se constrói o presente capítulo, no qual buscaremos fazer algumas análises acerca do caráter do Estado e sua relação com as classes e as lutas sociais na particularidade da formação social brasileira, explicitando a constante utilização das formas autocráticas de resolução dos antagonismos de classe e como estas formas ganham novas mediações no atual cenário político brasileiro do século XXI, a partir da ascensão de um governo que demonstra, de forma cada vez mais potencial, os seus traços neofascistas.

\section{A formação do Estado Nacional e a recorrente exclusão das forças populares da cena política.}

Caio Prado Jr. (2000; 2012) nos revelou que os eventos constituintes do processo da Independência e da formação do Estado nacional brasileiro representaram o fato de que a superestrutura política do Brasil Colônia não mais correspondia ao estado das forças produtivas e à infra-estrutura do país, rompendo-se para dar lugar a outras formas mais adequadas às novas condições econômicas e capazes de conter a sua evolução. Todavia, ao contrário de uma transição via revolução popular "ativa", desenvolvida quando uma classe ou bloco de classes hegemoniza a mobilização efetiva das massas populares, conduzindo-as a um rompimento radical com a velha ordem política e social (tal como se desenvolveu no processo jacobino), o processo aqui foi resultante de um "ambiente de manobras de bastidores".

Em outras palavras, diferente da experiência da América Hispânica ou inglesa - onde a história de ruptura com o pacto colonial, do processo da independência e da formação de um novo Estado-nação se revestiu, pelo menos em seu inicial impulso, das características de um típico processo revolucionário nacional-libertador -, a forma pela qual se construiu a emancipação no Brasil foi através de uma sequência de manobras "pelo alto", de conciliações "de cúpula" entre diferentes segmentos das elites dominantes, 
sob a qual a "luta se desenrola exclusivamente em torno do príncipe regente", e o poder é absorvido por completo por essas elites dominantes da excolônia, haja vista que tal processo foi acompanhado pela exclusão completa do protagonismo das camadas populares. (PRADO JR., 2012, p. 50-51).

Analisando os eventos que se abrem a partir de 1822, Octavio Ianni (2004) afirma que a Declaração da Independência, a construção da Assembleia Constituinte, os conflitos com os "portugueses" e as revoltas e revoluções populares ocorridas em diversas partes do país, não conseguiram lançar o Brasil em um patamar mais avançado da história, pois não desaguaram de imediato na abolição do regime de trabalho escravo, na Proclamação da República, no estabelecimento de garantias democráticas. 0 que se presenciou foi a derrota, o controle ou simplesmente a supressão dos movimentos e das ideias comprometidas com a república e com a democracia, além do paulatino - mas efetivo - encobrimento pelo manto monárquico das inquietações e das desigualdades presentes no país. Criou-se a ilusão de que a maioria dos problemas gerados com o escravismo, as nações indígenas, a questão agrária e as diversidades regionais poderia ser solucionada de forma benigna pelo poder moderador.

Com a neutralização de muitas inquietações, criava-se a oportunidade aos arranjos da conciliação pelo alto, fazendo prevalecer, assim, a continuidade colonial. 0 modo pelo qual se organizou o Estado nacional garantiu a continuidade das estruturas sociais herdadas do colonialismo. 0 equilíbrio "renovador-restaurador" germina-se para que se pudesse alcançar a Independência de modo cauteloso e sem a temerária participação "jacobina”. Afinal, o temor à revolução era um dos esteios do movimento pela Independência, e todos acordariam tanto com a forma de arranjo político quanto com ausência de participação popular, sob as quais se operaria o movimento.

A escolha da solução monárquica em detrimento da solução republicana deveu-se à convicção das elites no poder de que somente a figura do rei seria capaz de manter a união das províncias que constituíam a antiga colônia e sustentar a ordem social, em meio ao temor que a agitação e a violência traziam caso a opção fosse pela república. Mais ainda, o então chamado "haitianismo", com a proclamação da independência através da rebelião dos escravos e a expulsão da população branca, era um pesadelo próximo e temeroso para os proprietários rurais de um país dependente da 
mão de obra escrava e cuja população compunha-se de mestiços em dois terços do seu total ${ }^{2}$.

Exemplifica-se, aqui, o que Gramsci tratou como a principal preocupação do moderantismo conservador da revolução passiva: “[...] o temor pânico dos movimentos jacobinos, de qualquer intervenção ativa das grandes massas populares como fator de progresso histórico", o qual, por trás de "rutilantes ouropéis retóricos", esconde-se a

[...] inquietação do 'aprendiz de feiticeiro' e a intenção de abdicar e capitular diante da primeira ameaça séria de uma revolução [...] profundamente popular, isto é, radicalmente nacional (GRAMSCI, 2001, p. 291-292).

Exemplifica-se, aqui, o que Gramsci tratou como a principal preocupação do moderantismo conservador da revolução passiva:

[...] o temor pânico dos movimentos jacobinos, de qualquer intervenção ativa das grandes massas populares como fator de progresso histórico", o qual, por trás de "rutilantes ouropéis retóricos", esconde-se a "inquietação do 'aprendiz de feiticeiro' e a intenção de abdicar e capitular diante da primeira ameaça séria de uma revolução [...] profundamente popular, isto é, radicalmente nacional (GRAMSCI, 2001, p. 291-292).

O horror às sublevações populares é marca registrada das elites de todos os tempos. Apesar das tentativas de mobilização popular, a constituição da República na particularidade brasileira se realizaria tal como a Independência se realizara: sem a colaboração de um movimento de raízes populares. Nos meios republicanos, nutria-se a convicção de que os políticos civis eram corruptos, e de que a missão regeneradora, de salvação nacional, deveria ficar a encargo dos militares, os quais aparecem como o instrumento ideal para instituir um novo regime que colocasse as novas elites no poder. Dessa forma, a estratégia conspiratória prevaleceu sobre a estratégia revolucionária, e o novo regime que se instaura a partir de 1889 resulta de um golpe militar que, com a justificativa de solucionar os descontentamentos de setores importantes para a economia e a política no país, derruba a monarquia.

\footnotetext{
${ }^{2}$ Sobre o processo revolucionário haitiano, consultar o interessante trabalho de James (2000).
} 
A primeira Constituição da República incorporou o federalismo do modelo norte-americano proclamando uma estrutura de divisão dos poderes "harmônicos e independentes entre si" (o Executivo, o Legislativo e o Judiciário), como forma de tornar as instituições resistentes perante os "grupos facciosos", tal como receava os "Federalistas"3. Por outro lado, o liberalismo político dominante na Primeira República instituiu a autonomia dos Estados, o que interessava à oligarquia cafeeira e ao particularismo de seus negócios, contribuindo para a formação de amplos domínios fundiários onde prevaleceu a ordem latifundiária das elites agrárias imperiais. Cada Estado federado foi entregue à oligarquia regional como uma fazenda particular onde prevaleceria seu domínio, de forma que, satisfeita em suas solicitações, esta oligarquia ficasse com a tarefa de solucionar os problemas desses Estados, inclusive pela dominação, com a força, de quaisquer manifestações de resistência.

Com a sustentação do poder radicada na propriedade da terra e na riqueza, o coronelismo conforma-se, assim, como um fenômeno indicador da rarefação do poder público frente ao poder privado, estendendo à república constitucional liberal suas formas de mando e estratégias de garantia de eliminação dos interesses populares no âmbito político. Estruturou-se uma política na qual, por sobre (ou às custas de) os interesses do povo, o Presidente da República, os governadores estaduais e os coronéis articulavam-se como um vasto aparelho estatal de fato, o que garantia a submissão do legislativo ao executivo (em todos os níveis), e o afastamento dos interesses populares e urbanos que tentaram se fazer presentes no movimento republicano. Assim como fez o Império desde 1840, também a República se descartava do mais perturbador e anárquico de seus componentes, o povo. A vida social brasileira do período da Primeira República foi marcada pelo profundo traço do uso permanente, ilegal e impune do aparato repressivo para estancar o protesto dos espoliados, tirar de circulação a força de trabalho desnecessária e restaurar a ordem social nos moldes requeridos pelos interesses da classe dominante.

Percebe-se que esse medo ancestral de povo que tomava de assalto a classe dominante veio se transmutando desde os tempos da escravidão, quando a desconfiança em relação às camadas populares era tão generalizada quanto o horror a uma sublevação de escravos, reprimindo-se com violência desmedida as reações de rebeldia tanto nas fazendas como nos quilombos e aldeias, através de um extermínio que mobilizou verdadeiras operações de guerra. Este "medo ancestral" tanto mais se metamorfoseava e se

\footnotetext{
${ }^{3}$ A esse respeito, cf. Federalista (2005).
} 
potencializava quanto mais a transição do trabalho escravo para o trabalho livre fez aumentar a concentração no espaço urbano de segmentos de classe privados de meios de existência. Foi esta a forma através da qual se confirmou, no Brasil, a transmutação do recurso ideológico que se fez fortemente presente na Europa do século XIX, de justificação do domínio de "civilizados" sobre "primitivos", de brancos sobre não-brancos entre metrópoles e colônias como subsídio para a justificação do domínio de ricos sobre pobres.

Entre 1930 e 1937, o Brasil viveu uma fase de muitas incertezas e grande agitação política que culminaram na instauração de um novo tipo de Estado, marcado por extraordinária centralização do poder, implementando, com um discurso nacionalista, um "governo forte" cujo objetivo era transferir para si as bases de poder arraigadas nos regionalismos. A anterior Carta Magna era esfacelada pela "Aliança Liberal" que chegou ao poder com a "revolução de 1930".

As fronteiras do curto período de regime "democrático" efetivado nos anos 1930 se revelam mais claramente após a "revolução constitucionalista" de 1932. Mantém-se uma concepção de democracia e cidadania estreita e formal, que supõe como manifestação política adequada aquela que se dá dentro dos limites previstos no sistema legal, nas modalidades de participação internas aos mecanismos legais de representação, sobretudo a introdução do voto secreto e das mulheres e a criação de uma justiça eleitoral.

A necessidade de se encontrar uma saída para os problemas conjunturais (a eliminação do poder das elites partidárias e regionais) somouse à compreensão da necessidade de uma nova maneira de construir uma representação política considerada mais adequada ao caso nacional (partindo-se da premissa da fraqueza da sociedade e consequentemente, da tendência à perversão da representação). A resolução de ambas as tarefas se efetivava como um remédio plausível contra a ameaça do agravamento e da radicalização da luta de classes no país. Conformava-se, assim, uma faceta da modernização da sociedade brasileira, após o fim da República Velha.

0 saldo desse cenário foi a promulgação de uma carta constitucional (1934) que se aproximava fortemente do modelo social-democrata europeu, (principalmente, nos capítulos referentes à ordem econômica e social, à família, à educação e à cultura) ao mesmo tempo em que não alterava as estruturas de propriedade herdadas de quatro séculos passados nem sinalizava alterações no tocante à Reforma Agrária. Com o recrudescimento da luta política após a constitucionalização do país, aprofunda-se o período 
de "marchas e contramarchas", através dos quais o grupo que se acha no poder recompõe o aparelho estatal em uma nova estruturação.

Com a instauração da ditadura de Vargas em 1937, consolida-se o processo de transformação "pelo alto". Como reação aos movimentos populares, reais ou potenciais - os quais após um longo período de recrudescimento do caráter repressivo só conseguiram alcançar manifestações nos limites do subversivismo esporádico e elementar (GRAMSCI, 2001) - as classes dominantes reagiram e se empenharam em "restaurações" que, em última instância, acolheram uma certa parcela das exigências provenientes "de baixo".

Fortaleceu-se o poder da burguesia industrial e financeira, cujo objetivo imediato era, através da ativa intervenção do Estado, promover a industrialização do país sem grandes abalos sociais. A defesa por parte do regime autoritário veio acompanhada, nos intelectuais do regime, a classificações do mesmo como "um novo tipo de democracia", "adequada" às necessidades da sociedade brasileira: uma democracia sem povo, sem eleições e eleitores, pela via autoritária-elitista a partir do Estado centralizado, cuja "mão de ferro" saberia guiar os passos da nacionalidade para o engrandecimento do Brasil.

Um traço importante no tocante a este período refere-se ao fato de que a neutralização violenta dos "subversivos" como forma de desmobilização e despolitização da classe trabalhadora preparou o terreno para a sustentação da concepção de "harmonia" e "integração" entre as classes sociais, mas dessa vez sob a forma de uma legitimação e reconhecimento da questão social no interior do Estado, cuja "solução" adotava o disfarce da "dádiva", do "favor" de uma elite governante "benevolente" capaz de antecipar as soluções necessárias para o bem-estar dos trabalhadores sem a necessidade de grandes confrontos. Traveste-se no discurso apologético da "outorga" o fato de que a legislação social na verdade era resultante de todo um histórico de lutas. Passa-se a tratar como "benesses" a um povo cuja predisposição ao "espírito pacífico" não abria espaço para empreitadas violentas em longos processos de lutas.

Tais argumentações nos trazem importantes chaves analíticas para pensarmos as fases posteriores de consolidação da "democracia vulgar" 4 no cenário brasileiro. No período entre 1945 e 1964, com o alcance da fase denominada de industrialização pesada (principalmente entre 1956 e 1961), formata-se o cenário onde, segundo as formulações de Florestan Fernandes (1976) se completará a revolução burguesa e a constituição do

\footnotetext{
${ }^{4}$ Sobre a construção do conceito de "democracia vulgar", cf. Barboza (2014).
} 
capitalismo no Brasil. Este processo da industrialização brasileira, ainda que retardatário, está na base das pressões democráticas que, segundo Weffort (2003), as "classes populares" exercem sob o Estado no Brasil de 1945 a 1964, pressões estas referentes às possibilidades de ascensão socioeconômica e de consumo, desencadeadas com a migração campo-cidade em face do processo de urbanização e das péssimas condições de vida nas áreas rurais.

Considerado por muitos como o período "efetivamente democrático", esta democracia realizar-se-á sob as bases de um cenário considerado pela historiografia brasileira como o auge do populismo como poder ideológico de Estado, garantindo a transição da hegemonia da burguesia cafeeira para a burguesia industrial. Seus componentes fundamentais, segundo Weffort, podem ser resumidos em três: a "personalização do poder"; a imagem (meio real, meio mítica) da soberania do Estado sobre o conjunto da sociedade; e a necessidade de participação das massas populares urbanas (WEFFORT, 2003). Ou seja, o ritmo do desenvolvimento econômico e social que anteriormente propiciou o surgimento das classes populares e que passou a manter a vigência das alianças populistas deve ser preservado e intensificado (Ibidem, p.183).

Como a pressão popular se dirige sobre a ampliação do consumo, da regulação sobre a exploração capitalista e da participação política, o desafio imposto à política populista é compatibilizar desenvolvimento econômico com desenvolvimento democrático, o que, nos marcos da experiência contraditória da formação social dessas classes populares e de consolidação do caráter vulgar da democracia, impulsiona uma conquista da cidadania (ou mais especificamente da igualdade de direito) que cria a possibilidade de que se manifeste a insatisfação perante a desigualdade, porém sem de fato eliminar esta desigualdade.

Ao se reportar ao período correspondente aos governos de Juscelino Kubitschek e Jânio Quadros, Mirian Limoeiro Cardoso (1978) afirma que a centralidade conferida ao desenvolvimento estava indissociavelmente vinculada à ordem capitalista, onde os setores financeiros operaram vultuosos e lucrativos empréstimos que aprofundaram a condição capitalista dependente vis-à-vis ao núcleo do capitalismo. E este processo ocorre exatamente num contexto em que, segundo Florestan Fernandes (1981b), ocorrem profundas contradições, conflitos e embates advindos do ajuste das frações burguesas locais ao capitalismo monopolista, e que a defesa do desenvolvimento como parte estratégica etapista preconizada pelos seto- 
res mais influentes da esquerda teve como resultado uma derrota amarga dos trabalhadores.

Ou seja, o "oco dentro do oco" dessa democracia que se efetiva no quadro brasileiro é tão revelador que, no momento de um novo recrudescimento das reivindicações populares, de crise econômica e dissensos no bloco de poder sobre o direcionamento da sociedade, ela já havia configurado novamente o cenário propício para que a vulgarização democrática servisse de antessala para o restabelecimento do autocratismo tão funcional aos interesses centrais do capitalismo: a acumulação desenfreada despreocupada em ter que arcar com a trágica tarefa democrática de incorporação das classes populares ao processo político. Mais além, o caráter de simulacro do simulacro desta democracia vulgar é tão funcional aos interesses das classes dominantes que, ao instaurarem a ditadura a partir de 1964 com o suporte da "doutrina de Segurança Nacional", os militares a invocam sobre o pretexto de "purificar a democracia de seus elementos subversivos".

\section{Um novo ciclo político da dominação burguesa no Bra- sil: a autocracia burguesa a partir do golpe de 1964}

É fundamental considerar o contexto internacional no qual foi engendrado o golpe de 1964. O mundo experimentava um grande tensionamento entre as lutas de libertação nacional e social que explodiam em algumas partes do chamado "Terceiro Mundo" e a contrarrevolução preventiva levada a cabo pelas grandes potências capitalistas em escala planetária. Com efeito, seria impossível compreender a formação do regime ditatorialterrorista que assolou a sociedade brasileira e operou uma reprodução ampliada dos seus problemas estruturais sem reconhecer sua ligação com os mais reacionários interesses ocidentais.

Todavia, como argumenta José Paulo Netto ${ }^{5}$, importa privilegiar os vetores endógenos do movimento que escancarou a autocracia burguesa no Brasil. De acordo com esse autor - com base em clássicos do pensamento social brasileiro como Prado Jr. (1963), Sodré (1964), Fernandes (1976), Guimarães (1963) e Chasin (1978) -, as linhas de força que mais se destacaram na constituição da particularidade histórica em questão dizem respeito, basicamente, a uma estrutura predominantemente voltada para o mercado externo; à ausência de uma ruptura substantiva com o estatuto

\footnotetext{
5 "[...] a significação do golpe de abril, sem menosprezo da contextualidade internacional, deve ser buscada na particularidade histórica brasileira” (NETTO, 2005, p. 17).
} 
colonial; a uma burguesia incapaz de enfrentar o latifúndio e incapaz de realizar tarefas nacionais clássicas; a uma industrialização tardia combinada com uma monopolização precoce das atividades econômicas.

Daí porque o desenvolvimento capitalista e a formação do Brasil moderno não acarretaram em alterações efetivas na brutal concentração de terras nas mãos de uma oligarquia agrária e no caráter radicalmente restrito do poder e das esferas de decisão política. A crise aberta no início da década de 1960 expressava justamente a possibilidade de uma inflexão na forma heterônoma e excludente das relações econômicas e políticas no Brasil. Embora não representasse uma alternativa imediata à própria ordem capitalista, ao questionar o modelo de desenvolvimento vigente, o am plo bloco social que pressionava por reformas de base e participação popular colocava em xeque elementos essenciais da formação social brasileira.

Diante do impasse, a solução golpista trouxe, ao mesmo tempo, aspectos de conservação e mudança nos rumos do processo histórico. Conservação porque recuperou e consolidou os elementos mais antidemocráticos, antinacionais e antipopulares de toda a trajetória política do país. Mudança porque proporcionou uma imposição sem precedentes da dominação dos monopólios imperialistas e da oligarquia financeira global sobre quase todos os demais setores da sociedade brasileira. Era necessário não apenas institucionalizar, como também induzir o processo de concentração e centralização de capitais no Brasil.

Assim, as forças econômicas e políticas mais reacionárias do País, ajustadas às exigências do capital monopolista e aliadas ao imperialismo, organizaram e realizaram o golpe de Estado, instalando uma ditadura da burguesia, abrangente e poderosa, a serviço do grande capital financeiro e monopolista, de modo direto, ostensivo e repressivo. Era necessário criar as condições políticas e econômicas para a retomada do "desenvolvimento" (cujas bases principais já tinham sido postas no governo de Juscelino 1956/1960); criar condições práticas e ideológicas para garantir a "segurança interna", o que envolvia o controle e a repressão de toda a organização e atividade política das classes assalariadas, para que as "forças do mercado" pudessem se desenvolver amplamente, com o predomínio da "livre empresa" no sistema econômico (IANNI, 2019).

0 ciclo dos generais, contudo, não se desenrolaria de maneira homogênea. A ditadura brasileira começou buscando legitimação na sociedade, mas tal intuito se veria frustrado tanto pela natureza antidemocrática e antipopular de seu projeto de poder e de sua política econômica quanto pela ação diuturna da resistência. Foi por isso que, ao final dos anos 1960 
(notadamente a partir de 1968) o regime mudou seu modus operandi. É nesse momento que a ditadura realiza um verdadeiro ajuste estrutural no Estado brasileiro, fundindo o aparato dos monopólios e o aparado estatal.

De acordo com Ianni (2019), a ditadura militar passou a criar condições jurídico-políticas e econômicas sob as quais a taxa de mais-valia potencial passou a se realizar em taxas extraordinárias de mais-valia. A maneira através da qual o Estado ditatorial dinamizou a política econômica governamental acentuou, sob diversas formas, a exploração da força de trabalho, agravando as condições de pauperização relativa do conjunto da classe operária e a pauperização absoluta de amplos setores dessa classe. A violência concentrada e organizada do poder estatal é transformada em técnica produtiva, e passa a atuar no sentido de garantir e reforçar a subordinação econômica e política da classe operária e do campesinato. Em outras palavras, para que fosse possível a concretização da economia política governamental, era necessário um amplo aparelhamento estatal. Assim, a ditadura tomou como herança dos governos anteriores toda a parafernália burocrática e tecnocrática do poder público, em termos de órgãos, pessoal e recursos materiais, a qual foi rearticulada e dinamizada em função das exigências da sistemática da política econômica adotada.

À medida que o modelo econômico exclui e o regime político se fecha, a militarização da sociedade avança e o terrorismo de Estado torna-se o eixo da dominação do grande capital, varrendo da frente qualquer obstáculo à "modernização conservadora" ${ }^{6}$. Por um lado, se intensifica um processo singular de militarização do Estado e de Instituições paraestatais e privadas. Baseada na doutrina de "segurança e desenvolvimento", instaura-se a regra de suspeição geral e difusa, sob a qual acusa-se a sociedade civil de incompetente, amorfa, porém potencialmente perigosa e sujeita à "subversão e corrupção". Essa imagem fascista da sociedade serviu de justificativa para a conformação de um Estado forte, abrangente e repressivo, capaz de se precaver contra os subalternos e subordinados (ou seja, o conjunto das categorias sociais que não se encontravam dentro do bloco do poder). Subordinado totalmente ao Poder Executivo, o conjunto do aparelho estatal é transformado numa máquina civil-militar-policial; uma instituição autossuficiente e todo-poderosa que, ao mesmo tempo em que oprimia o trabalhador, paralelamente imputava políticas que atendiam aos interesses particulares do grande capital financeiro e monopolista (IANNI, 2019).

Por outro lado, desenvolve-se uma dinâmica de militarização do processo de trabalho, das relações de produção, em amplitude nunca antes

\footnotetext{
${ }^{6}$ Sobre o conceito de "Modernização Conservadora", cf. Moore Jr. (1975).
} 
enfrentada pela classe operária brasileira. 0 aumento da taxa de exploração da força de trabalho teve como contrapartida o reforço dos mecanismos de organização e funcionamento - ou dos princípios de hierarquia, disciplina e desempenho dentro da fábrica - os quais eram justificados pelos empresários através dos princípios de "melhoria da produtividade e da eficácia". Assim, em escala ampliada, as condições de trabalho na fábrica foram submetidas às exigências da doutrina de "segurança e desenvolvimento" e os mecanismos de "modernização" do processo produtivo envolveram as mais diversas formas de punição, o que revelava a abrangência da violência política, policial e militar para além do aparelho repressivo (Ibidem).

Cada vez mais afastada da noção de democracia, a estratégia de legitimação da ditadura se desloca para a propaganda do "milagre brasileiro". Sob a ficção perversa de um modelo econômico que transformaria o Brasil numa "potência mundial", toda força concentrada e organizada da sociedade foi posta a serviço de uma política destinada a superar a "estagnação econômica" e a "inflação explosiva", sob a qual a ditadura organizava e concentrava a violência estatal em conformidade com a violência da acumulação capitalista (IANNI, 2019).

A euforia econômica, entretanto, teria vida curta. Em 1973, já era possível atestar a falência do modelo de crescimento acelerado. E sua crise correspondia à crise da própria ditadura empresarial militar. 0 esgotamento do "milagre brasileiro" já revelava que não haveria frutos a serem redistribuídos: as mesmas forças expansivas do capital que, por um lado, geraram mudanças estruturais engendradas pela industrialização e a urbanização no país, por outro lado impulsionaram uma saturação do espaço social brasileiro com todas as refrações da "questão social" hipertrofiadas (NETTO, 2005), cujo aprofundamento resultou num volume significativo de demandas represadas. Massacrado pelo arrocho salarial, o proletariado não demoraria a se rebelar. A exposição destas fraturas no projeto do grande capital e a possibilidade de constituição de uma vontade popular radicalizada impulsionou, como contrapartida, a gestação do autodenominado processo de "distensão" de regime, abrindo caminho para uma transição "lenta, gradual e segura"; um projeto de abertura "pelo alto", fortemente seletivo, baseado tanto na cooptação de alguns elementos moderados da oposição, quanto na exclusão e repressão de seus segmentos mais radicais - particularmente aqueles ligados aos setores populares.

Todavia, a crise da ditadura estava longe de ser uma crise mais ampla do Estado. Em meio a diferentes momentos, com nuances e especificidades, pelo menos dois componentes fundamentais se mantêm ao longo de 
todo o processo entre a segunda metade da década de 1960 e o início da década de 1980: a doutrina de segurança nacional e a hegemonia burguesa. Elementos que conectam os "anos de chumbo" ao período de "abertura", ambas perpassam o período bonapartista, criando dispositivos permanentes junto ao Estado e determinando sua estrutura para além da ditadura. Nesse sentido, Antônio Carlos Mazzeo demonstrou como o processo de "redemocratização" na verdade atualizou a autocracia burguesa e suas formas institucionais. Segundo o autor, "a visão ideológica de uma sociedade civil restrita aos que possuem capitais (originária dos tempos coloniais) não foi suplantada" (MAZZEO, 1995, p. 73).

\section{A retomada da mistificação do "Estado democrático de direito": as contradições da "Nova República"}

A troca da ditadura por um governo de "conciliação conservadora" se tornou o desdobramento mais conveniente às elites econômicas, culturais e políticas das classes dominantes, traduzindo perfeitamente o que estas são capazes de fazer no plano das atividades políticas esterilizadas e sem risco: a montagem política e ideológica de um Frankenstein, batizado de "Nova República". Enquanto todo o seu sistema de poder e de propagação ideológica alardeou essa mistificação monstruosa como uma "vitória do Povo na luta pela democracia!", a realidade para além do embuste demonstrou que a grande vitória foi desfrutada pelos militares e civis comprometidos com a "transição lenta, gradual e segura", a qual não se resumiu à sua capacidade de determinação do sucessor e das condições políticas desta "transição" - através da efetivação do pacto político pelo qual a escolha da sucessão presidencial foi transferida definitivamente para o colégio eleitoral. Apesar deste ser o objetivo central, o desígnio mais importante e essencial para apaziguar o temor dos militares e dos extratos mais reacionários da burguesia era a neutralização da possibilidade de uma transferência de poder com uma acelerada acumulação de forças políticas das classes subalternas (FERNANDES, 1986).

Nestes marcos, não é exagero afirmar que, mesmo após a "abertura", os militares continuaram numa posição politicamente preeminente no primeiro governo civil pós-ditadura, exercendo uma espécie de "tutela" sob o mandato de José Sarney. Após ver seu plano de estabilidade econômica fracassar (Plano Cruzado), no final de 1986, Sarney (um filhote da ditadura que já costumava prestigiar publicamente a 
instituição e seus ministros militares) passou a buscar cada vez mais sustentação nas forças armadas.

O saldo dessa revigorada confiança recíproca entre o presidente eleito e os militares não foi alentador para o final da década de 1980 . Por um lado, percebe-se um Estado com um enorme déficit de controle democrático, vulnerável aos interesses dos grandes grupos econômicos, privatista na sua estrutura de benefícios e subsídios fiscais e com o Executivo reforçado em detrimento dos demais poderes. Por outro, fermenta-se uma mistura explosiva que forjou uma situação de crise profunda até o encerrar daquela década: a economia numa situação que beirava a hiperinflação, a incapacidade de solucionar o problema do endividamento de forma consistente, investimentos públicos e privados em níveis pífios e a agudização das expressões da questão social. (BEHRING, 2003). Tal cenário impulsionou o avanço da mobilização e da organização dos movimentos sociais e populares, tendo sua significativa expressão na ascensão do movimento grevista (chegando à marca de quatro mil greves em 1989). A reação do Governo Sarney foi o reforço da utilização dos militares como interventores diretos no conflito político e social, como foi o caso da interrupção da greve dos metalúrgicos através da invasão das tropas do exército na Companhia Siderúrgica Nacional, em 1988.

Com este quadro, a tarefa de retomada do "Estado democrático de direito" não ficou a encargo de uma Assembleia Nacional livre e soberana, como era a reivindicação do conjunto do movimento dos trabalhadores e dos movimentos sociais, mas sim designada para um Congresso Constituinte, num processo duro de mobilizações e contramobilizações de projetos específicos, que o transformou numa grande arena de disputas com campos de forças bem definidos.

A conformação de protagonistas políticos dispostos a enfrentar as enormes contradições econômicas e o controle financeiro e militar serviu de alavanca para uma interferência significativa desses estratos na agenda política ao longo dos anos 1980. A ascensão do movimento operário e popular - que fora potencializada pelas mudanças estruturais geradas pela industrialização e a urbanização - ajudou a pautar alguns eixos da Constituinte como, por exemplo, a reafirmação das liberdades democráticas, de uma vontade nacional e da soberania (contrapondo-se às interferências do FMI) e a afirmação dos direitos sociais e trabalhistas. Todavia, também já se encontravam presentes na arena as expectativas de mudança na direção de uma nova agenda neoliberal. 
Por sua vez, as assessorias militares, que levavam todas as informações necessárias para a discussão entre os chefes militares, tiveram os seus tamanho e status aumentados no Congresso. Intensificou-se a atuação dos ministros militares e de seus assessores parlamentares junto às lideranças da Constituinte, caracterizando um eficiente lobby militar articulado não somente pelos ministros das três forças, como também pelos chefes do Serviço Nacional de Informações (SNI) e do Estado Maior das Forças Armadas (EMFA).

Este cenário de disputa de hegemonia traduziu-se, em 1988, numa Constituição Federal que contemplou significativos avanços no âmbito dos direitos sociais, mas reforçou a permanência de fortes traços conservadores, como a manutenção de prerrogativas do Executivo (a exemplo das medidas provisórias) e a manutenção da destinação constitucional das Forças Armadas como mantenedoras da lei e da ordem, em caso de convulsões internas. Porém, a rearticulação das classes dominantes foi muito além dos rearranjos políticos e jurídicos, avançando para o terreno da reestruturação produtiva. Deste modo, a subordinação do parque industrial nacional aos parâmetros da assim chamada globalização contribuiu para reforçar a subsunção real do trabalho ao capital. De acordo com Castelo (2013, p. 342),

[...] produziu-se, assim, uma derrota estrutural no plano econômico que permaneceu subterrânea até os anos 1990, quando transformações neoliberais na superestrutura vieram consolidar e aprofundar a supremacia burguesa.

As transformações neoliberais que desenterraram a derrota estrutural da classe trabalhadora colocaram a supremacia dos setores burgueses em outro patamar. Uma vez que a possibilidade de um caminho pela esquerda para o desenvolvimento capitalista no Brasil fora historicamente sepultada com a ditadura e o campo socialista sofrera uma grave derrota com a desagregação da União Soviética entre 1989 e 1991, estavam dadas as condições para o reordenamento econômico, político e social do Brasil no sentido de abolir mecanismos protecionistas, privatizar empresas públicas e desmontar os tímidos direitos sociais e trabalhistas ainda existentes.

Assim, a transição entre o final da década de 1980 e o início da década seguinte se formata num amplo processo regressivo pautado nos postulados do receituário neoliberal. Se as lutas sociais empenhadas na necessidade de profundas transformações no direcionamento político-econômi- 
co do país conseguiram alcançar algumas conquistas na Carta Constitucional de 1988, estas foram violentamente atacadas pelas forças da sociedade alinhadas às diretrizes das agências multilaterais encarregadas de tomar as decisões estratégicas do capital. Passa-se a exercer uma pressão para a redefinição das funções do Estado, abolindo o seu controle sobre o movimento do capital e as condições de utilização da força de trabalho, e retirando as suas obrigações de proteção e garantia das políticas sociais públicas para que as suas atividades no campo econômico e social pudessem ser entregues aos negócios privados.

A guinada rumo a esse conjunto de (contra) reformas - centradas fundamentalmente nas políticas de ajustes, privatização, desregulamentação e flexibilização das leis trabalhistas - inicia-se a partir de 1990, quando Fernando Collor de Mello assume a presidência do País pelo inexpressivo Partido da Reconstrução Nacional (PRN). Num cenário banhado por uma cultura política da crise que defendia a retomada do crescimento econômico e a necessidade de redefinição do papel do Estado devido a sua suposta ineficiência para a resolução desta crise (MOTA, 1995), Collor implementa um plano de estabilização da economia por meio da adoção de políticas deflacionárias e uma série de medidas extremas ${ }^{7}$, acompanhadas de uma política monetária restrita e do fortalecimento da abertura comercial, com a adoção de medidas de liberação do câmbio e outras ações direcionadas à abertura da economia brasileira ao capital internacional. Fracassado em suas políticas de estabilização, e envolvido em escândalos de corrupção, Collor sofre um impeachment no final de 1992, e seu vice "tapa buraco" Itamar Franco dá sequência ao programa de reformas liberalizantes e privatizantes, alcançando momentaneamente a estabilização econômica através do "Plano Real".

\section{A consolidação da era neoliberal e a necessária rees- truturação do aparelho de Estado}

A consolidação das políticas neoliberais se intensifica, em forma e substância, nas duas gestões de Fernando Henrique Cardoso (FHC) na chefia do executivo federal (1995-2002). FHC incrementou a efetivação das medidas de ajuste fiscal e monetário, potencializou a abertura da economia e realizou uma intensa reestruturação do aparelho de Estado, conforme di-

\footnotetext{
${ }^{7}$ Como, por exemplo, o congelamento de preços e salários, o bloqueio de poupanças, a demissão de servidores públicos e a introdução de uma nova moeda.
} 
retrizes estabelecidas pelo Plano Diretor da Reforma do Estado (PDRE) ${ }^{8}$, profundamente alinhado às formulações de Bresser Pereira, então à frente do Ministério da Administração e da Reforma do Estado (MARE). 0 discurso se centrava na acusação do caráter "atrasado" e "perdulário" da constituição de 1988 e na necessidade de ultrapassar a herança tradicional, burocrática e centralizada da administração pública, considerando o esgotamento da "estratégia estatizante".

A crescente radicalização da questão social e a refração do Estado no enfrentamento da mesma, a privatização no atendimento das necessidades sociais das grandes maiorias, o crescimento das organizações não governamentais e a precarização do emprego foram as principais marcas da "onda neoliberal" que assolou o país. As já precárias condições sociais da grande maioria da população se agravaram de forma crescente com as irreparáveis perdas sofridas pelas políticas sociais universais, como Previdência, Saúde, Assistência e Educação Básica.

Para que o capital pudesse garantir sua reprodução e ampliação em tempos de (des)ajustes neoliberais, a ascensão de um violento processo de criminalização em direção às classes subalternas tornou-se um aspecto orgânico da sua política de controle social, reciclando-se a noção de "classes perigosas" sujeitas à repressão e extinção. Tratar a luta pelos direitos sociais como "delitos" e os sujeitos sociais envolvidos nessas lutas como "delinquentes" ou "vândalos" se conformou como a principal ação cultural presente no núcleo desse processo de criminalização dos movimentos populares/sociais (KOROL, 2008).

Articulam-se diversos planos da estratégia de dominação, que vão desde a criminalização da pobreza e a judicialização do protesto social até a repressão política aberta e a militarização dos territórios - modalidades estas que adquirem maior ou menor relevância de acordo com o momento histórico concreto (Ibidem). Conforme explicitado em um documento da Via Campesina, esta criminalização objetiva criar, perante a sociedade, condições legais (e, se possível, legítimas) para: impedir que a classe trabalhadora alcance conquistas econômicas e políticas; restringir, ou diminuir o acesso destas classes às políticas públicas; construir um processo de isolamento e desmoralização dos movimentos sociais e criar condições legais para a repressão física aos movimentos sociais (VIA CAMPESINA BRASIL, 2010, p. 6). Assumindo novos vieses, tal estratégia se formata como um fenômeno multifacetário onde se entrelaçam, em todas as dimensões, aspectos jurídicos, econômicos, culturais, sociais e militares; isto é, uma ação

\footnotetext{
${ }^{8}$ A esse respeito, cf. MARE (1995).
} 
conjunta dos setores do aparato estatal repressivo, do poder Legislativo e do Judiciário, da mídia e do sistema educacional (BUHL; KOROL, 2008).

Um exemplo paradigmático deste direcionamento se revela no programa de governo construído por FHC, em 1994. Ao afirmar que a causa da violência e da criminalidade não seria apenas derivada da miséria e das injustiças sociais, mas também da ausência da capacidade do poder público em aplicar as leis - já que a máquina do Estado brasileiro estaria "quebrada" -, FHC deixa claro que o objetivo central do seu primeiro mandato (que se manteria no segundo) seria ampliar e melhorar a capacidade das agências governamentais de aplicar a lei e a ordem, fortalecendo as agências próprias do sistema de segurança e justiça ${ }^{9}$.

Os efeitos para o proletariado foram nefastos. 0 aumento do desemprego, bem como a precarização das relações de trabalho e das condições de vida da maior parte da população criaram um solo fértil para o discurso contra os "privilégios" de servidores públicos, intimidando também operários com certa estabilidade no setor privado. Assim, segmentos importantes do movimento sindical foram colocados na defensiva e aumentou a fragmentação da classe trabalhadora. Enquanto isso, no andar de cima, ampliava-se a coesão do bloco burguês, beneficiado com o aumento da exploração da força de trabalho, a mercantilização de uma gama cada vez mais vasta de atividades e o assalto ao fundo público.

As análises desse processo, no entanto, suscitam enormes polêmicas. Para alguns, o neoliberalismo corresponde ao processo de desindustrialização na América Latina. Daí se compreende que o setor mais prejudicado seria a burguesia produtiva, em benefício do rentismo, do capital especulativo e do imperialismo. A consequência política desta concepção é o ressurgimento de posições nacionalistas e (neo)desenvolvimentistas. Para outros, a eliminação das fronteiras entre nações e ramos econômicos, isto é, entre as burguesias local, global, industrial, bancária, comercial etc., teria desencadeado um movimento de homogeneização da burguesia. Essa burguesia homogênea, portanto, se beneficiaria indistintamente do neoliberalismo ${ }^{10}$. Segundo Boito Jr. (2002, p. 18),

\footnotetext{
9 "[... não se trata de escolher entre o Estado-polícia e o Estado de bem-estar social. Primeiro, porque não há democracia sem obediência à lei que, em última análise, depende do poder coercitivo do Estado. Segundo, porque a capacidade do Estado de prover bem-estar depende, em larga medida, do seu poder coercitivo [...]." (CARDOSO, 1994, p. 161-162)

${ }^{10}$ As considerações acima, com poucas alterações, tem como referência o texto de Boito Jr. (2002).
} 
Para compreender essa situação complexa, precisamos desagregar a política neoliberal em cada uma de suas partes componentes e cotejar cada uma delas com os distintos interesses da burguesia. Podemos pensar os pilares da política neoliberal como uma série de três círculos concêntricos: a) o círculo externo e maior representando a política de desregulamentação do mercado de trabalho e de redução dos direitos sociais; b) o círculo intermediário, representando a política de privatização e c) o círculo menor e central da figura, representando a abertura comercial e financeira.

Refutando as vertentes descritas anteriormente, o autor oferece ferramentas para uma análise mais precisa do fenômeno neoliberal no Brasil. Toda a burguesia tem interesse na desregulamentação do mercado de trabalho e na retirada de diretos sociais. Já as privatizações, para além do aspecto ideológico, atendem mais diretamente os anseios materiais dos monopólios - pois as regras dos leilões excluem pequenos e médios acionistas. Porém, mesmo entre os monopólios há uma hierarquia. A abertura comercial e financeira beneficia mais diretamente a burguesia financeira e o imperialismo, trazendo consequências no mínimo contraditórias para a burguesia industrial. Contudo, entre enfrentar o setor bancário do capital monopolista e o imperialismo ou transferir os efeitos da concorrência estrangeira, da redução dos investimentos produtivos e da política de juros para a classe trabalhadora, fica evidente qual tem sido a opção histórica dos industriais.

As políticas de ajuste fiscal - defendidas como a alternativa para retomar o desenvolvimento econômico, a criação de empregos e privilégios das políticas sociais - deixaram de ser solução e se tornaram a causa da crise, desequilibrando econômica e financeiramente o país, deixando o Estado cada vez mais enfraquecido externa e internamente e fragmentando cada vez mais a sociedade, com altos índices de desigualdade e de retirada dos seus direitos básicos. Na entrada do século XXI, os impactos sociais, políticos e econômicos desta crise enfraqueceram a legitimidade política e ideológica usufruída pelo neoliberalismo na última década do século anterior. A incapacidade das políticas neoliberais postas em prática aprofundou a crise social existente, sem conseguir nem retomar o desenvolvimento nem conquistar estabilidade política, gerando ampliação da desigualdade econômico-social e instabilidade institucional.

Neste cenário, pressionados pelo recrudescimento das lutas sociais antissistêmicas derivadas da crise das políticas neoliberais de primeira geração, os setores dominantes abertos à revisão do Consenso de Washington 
conseguiram atrair para o seu bloco de poder importantes setores de seus antagonistas, conformando um processo transformista que contribuirá para formatar a chegada do Partido dos Trabalhadores à presidência da República em 2003.

\section{O Estado sob a hegemonia da pequena política}

Parafraseando Marx ${ }^{11}$, todos os fatos e personagens de grande importância na história ocorrem, por assim dizer, duas vezes: a primeira como tragédia e a segunda como farsa. Na década de 1960, a Estratégia Nacional Democrática, preconizada pela principal força política operária e popular da época, o Partido Comunista Brasileiro (PCB) afirmava, grosso modo, que o Brasil era um país semifeudal, de modo que a burguesia nacional poderia cumprir um papel progressista na aliança contra o latifúndio e o imperialismo, criando as condições para a realização da etapa nacional e democrática da revolução. Apoiado por amplos segmentos empresariais, o golpe de 1964 eliminou na prática a tese de que haveria uma contradição estrutural entre a burguesia, o latifúndio e o imperialismo. Cabe ressaltar, porém, que, mesmo equivocada, havia na estratégia do PCB um caráter revolucionário e explicitamente anti-imperialista.

0 Partido dos Trabalhadores (PT), formado no ocaso da ditadura empresarial militar, identificava o neoliberalismo nos anos 1990 como um dos principais entraves, senão o principal, para a melhoria das condições de vida do povo brasileiro. Para derrotar esse modelo econômico seria necessária a formação de uma ampla frente neodesenvolvimentista, envolvendo a burguesia interna, a pequena burguesia e os trabalhadores. Considerando a correlação de forças desfavorável nos planos nacional e internacional, não seria possível realizar reformas ou encarar o imperialismo de frente. Não se tratava sequer de reeditar o desenvolvimentismo das décadas passadas, mas de tão somente realizar o desenvolvimento possível dentro dos marcos neoliberais e reduzir o protagonismo do capital estrangeiro e da burguesia a ele associada.

0 que foi apresentado como alternativa ao neoliberalismo se converteu em um eficiente instrumento de renovação da ordem neoliberal no Brasil, reduzindo, na prática, a disputa política nacional às disputas eleitorais entre social-liberalismo e neoliberalismo ortodoxo. Foi assim de 2002

\footnotetext{
11 "Hegel observou, certa vez, que todos os fatos e personagens de grande importância na história universal ocorrem, por assim dizer, duas vezes. E esqueceu-se de acrescentar: a primeira como tragédia e a segunda como farsa" (MARX, 2006, p. 15).
} 
a 2014, período em que o PT derrotou o PSDB em todas as eleições presidenciais.

Abre-se uma era de conciliação de iniciativas aparentemente contraditórias: as diretrizes do receituário liberal e a pauta desenvolvimentista, conformando uma apologia a um desenvolvimento fundado no equilíbrio entre crescimento econômico e desenvolvimento social, adjetivados de autossustentáveis econômica, social e ambientalmente. Através da mediação do mercado e do crescimento econômico induzido pelo Estado, o governo atendeu algumas das reivindicações das classes subalternas, ao mesmo tempo em que assegurou as exigências das classes dominantes. Na primeira etapa do governo Lula, por exemplo, enquanto se expandia a assistência social e aumentava-se o salário mínimo (concomitantemente com a expansão do crédito ao consumidor e dos empréstimos populares), realizavam-se também as contrarreformas da educação e da previdência e as sofisticadas privatizações indiretas da saúde, cultura e outras áreas sociais - através da administração terceirizada por organizações sociais e fundações.

Com ou sem prefixo "neo", o desenvolvimentismo passou a assumir uma extraordinária centralidade nas narrativas de todos os domínios: no domínio econômico, como uma alternativa ao Estado mínimo neoliberal; no domínio político, pois se associava ao novo progressismo dito de cariz pósneoliberal; e no domínio social, no sentido de que o seu compromisso mais profundo era com os denominados pobres, “[...] assegurando a estes renda mínima e certa socialização que os levam a serem 'pessoas com capacidade para fazer acontecer' alternativas econômicas” (LEHER, 2012, p.18).

Constitui-se, assim, conforme defende Francisco de Oliveira (2010), um processo de "hegemonia às avessas", um novo movimento constitutivo da hegemonia das classes dominantes, desenvolvido com as armas da despolitização em prol da conservação dos seus interesses. Coutinho (2010), amplia tal formulação afirmando que este movimento que comporta a convivência com os novos movimentos sociais e com algumas das reivindicações de necessidades sociais (como o acesso à renda e ao consumo) formata uma outra pedagogia: a da socialização da sociedade brasileira em que as demandas dos "de baixo" são atendidas no âmbito da "pequena política", como meio de sitiar a "grande política".

Como forma de justificativa para a continuidade da ortodoxia da política econômica neoliberal, os governos petistas perpetuaram um discurso oficial de que estávamos à beira do abismo, numa espécie de "estado de emergência permanente", que implicava (até mesmo para um Partido dos Trabalhadores) a necessidade de medidas as mais duras possíveis (PAULA- 
NI, 2010, p.123): elevação do superávit primário para além do exigido pelo FMI; aumento potencial da já elevadíssima taxa básica de juros; redirecionamento de recursos que poderiam ser utilizados em investimentos públicos para o pagamento do serviço da dívida; privatizações de hidrelétricas, portos e rodovias; aprovação de Leis que beneficiaram fundamentalmente o Agronegócio (como a Lei de Biossegurança, que autorizou a comercialização dos transgênicos); cortes em investimentos sociais e "equilíbrio das contas públicas" através do mecanismo de Desvinculação de Receitas da União (DRU); dentre outras estratégias ${ }^{12}$.

Além dessas aproximações com as propostas neoliberais anteriormente implementadas, os governos de Lula da Silva e Dilma Rousseff, com suas pequenas diferenças, não alteraram significativamente os propósitos do governo FHC no tocante aos programas preocupados com a garantia da "Lei e da Ordem". A adaptação à tática eleitoral "a qualquer custo" e a opção por grandes (e díspares) coalizões e coligações (que englobam de setores da esquerda à direita) contribuiu, por um lado, para a dissimulação dos conflitos de classe e, por outro, para a manutenção da estratégia de criminalização das lutas sociais, dos movimentos sociais e suas lideranças, abrindo portas para uma retomada das velhas práticas dos setores mais conservadores no país no tocante à neutralização das reivindicações dos diferentes extratos da classe trabalhadora. Dois exemplos são paradigmáticos.

Sob a justificativa da necessidade de políticas de segurança para a realização dos megaeventos desportivos que ocorreriam no país (Copa do Mundo e Olimpíadas) o Governo Dilma Rousseff implementa medidas de fortalecimento e maior integração das instituições de segurança (Forças Armadas, Polícia Federal e polícias estaduais). A Portaria Normativa n. 3461 (BRASIL, 2013), editada em 2013 pelo Ministério da Defesa, institui a Operação Garantia da Lei e da Ordem (Op GLO), a qual autoriza o uso das Forças Armadas como forças de segurança pública na ocorrência de situações onde haja uma "presunção de perturbação da ordem". Três anos depois, o mesmo governo Dilma enviou ao Congresso, trabalhou para aprovação e sancionou o projeto de lei 13.260/2016 que tipifica o terrorismo no país (BRASIL, 2016a). 0 conteúdo fascista da denominada Lei Antiterrorismo foi denunciado em amplos protestos de entidades de direitos humanos

\footnotetext{
${ }^{12}$ A Desvinculação de Receitas da União (DRU), juntamente com a Lei de Responsabilidade Fiscal (LRF), foram os dois principais mecanismos para se realizar os cortes em investimentos sociais desde os mandatos de Fernando Henrique Cardoso (e continuam vigentes até os dias atuais). Durante o Governo de Dilma Rousseff, a DRU não somente permaneceu vigente como também foi prorrogada até o ano de 2023, com a novidade de que o percentual de retirada de recursos orçamentários foi aumentado de $20 \%$ para $30 \%$.
} 
e da sociedade civil e foi rejeitada por parte da própria bancada do PT, o que exigiu, ao então governo, fazer alianças com políticos do DEM e do PSDB para que fosse possível aprovar a mesma tanto na Câmara quanto no Senado.

Em 2015, quando Dilma praticou um estelionato eleitoral e nomeou Joaquim Levy para comandar seu ajuste fiscal a partir do Ministério da Fazenda, esvaíram-se as pequenas diferenças existentes entre os projetos petista e tucano. A proximidade tão íntima entre estes projetos delimitou até que ponto poderia chegar os avanços dos governos do PT e também quais seriam os seus limites claros. Apesar dos governos Lula/Dilma terem alcançado algumas melhorias no âmbito social (através de estratégias - não isentas de controvérsias - de adoção de políticas sociais de distribuição de renda e de ampliação do mercado formal de trabalho e de crédito), estas não foram acompanhadas de alterações estruturais nos pilares que alicerçavam as políticas macroeconômicas no Brasil desde a década de 1990 (vinculação das taxas de juros Selic às metas de inflação, manutenção do superávit primário e relativa valorização do câmbio). Juntam-se, a esses elementos, algumas determinações conjunturais que moldaram o cenário para o declínio da hegemonia petista no poder do Estado.

Enquanto, externamente, intensificava-se a recessão global derivada da persistência da crise econômica internacional pós-2008 (agravada com os problemas da Grécia em relação a sua impagável dívida pública que foi o estopim para crise da Zona do Euro), internamente, o Governo Dilma Rousseff insistia nos equívocos das escolhas para a sua política econômica: seja pela opção das desonerações fiscais sem contrapartidas, no final do seu primeiro mandato; seja pela capitulação à agenda de seus adversários eleitorais ao adotar uma forte política de austeridade fiscal com viés recessivo, no início de seu segundo mandato (reeleição esta marcada por uma margem muito pequena na diferença de votos). Além disso, o período de 2013 a 2016 foi extremamente turbulento: grandes manifestações de rua explodiram trazendo uma diversidade de temas e problemas, cujas contradições se expressaram numa multifacetada aparição de elementos de bom senso contra a ordem ao lado de reapresentações de conteúdos conservadores e mesmo preocupantes do senso comum (como o nacionalismo exacerbado, o antipartidarismo, a retomada da extrema direita).

Ineficiente na construção do crescimento econômico e incapaz de rearticular sua base de apoio político e eleitoral, o PT passa a ser identificado como um governo gastador, estelionatário eleitoral e defensor estatal. Mais do que isso, passa a ser associado ao discurso da corrupção. Com a cri- 
ação da Operação Lava Jato, em 2014, o discurso moralista anti-corrupção ganha forma institucional e a articulação entre setores da Polícia Federal, do Ministério Público Federal e do Judiciário se fortalece para atacar os pilares de sustentação política que ainda restavam ao governo do PT, além de desestruturar parte importante da economia. Esse conjunto de eventos intensifica a fragilização do governo até desaguar numa crise política que ocasionou no impeachment da presidenta, sob a alegação de crime de responsabilidade, por sinal, inexistente.

\section{A retomada da ortodoxia liberal e o processo de fascis- tização do Estado}

Após o golpe institucional-jurídico-parlamentar-midiático que destituiu a presidenta em 2016, abre-se um curto, porém intenso, período de restauração do neoliberalismo ortodoxo com Michel Temer (PMDB). A despeito do seu alto índice de impopularidade registrado nas enquetes (a mais alta rejeição desde a instauração da "Nova República"), Temer conseguiu aprovar uma série de medidas de caráter antipopular, ancorado no expressivo apoio político que obteve a partir da construção de uma forte base parlamentar.

Dentre os ataques mais significativos, instituiu-se o chamado "Novo Regime Fiscal" a partir da Emenda Constitucional n. 95 (BRASIL, 2016b), a qual estabelece limitações orçamentárias para as políticas públicas durante 20 anos, onde as despesas primárias do orçamento público ficam limitadas à variação inflacionária. Outra ofensiva deste governo se conformou na aprovação da Lei da Reforma Trabalhista, Lei n. 13.467/2017 (BRASIL, 2017), que alterou mais de 200 pontos da CLT. Pautada no discurso da "necessidade de geração de novos empregos", a referida Lei, na verdade, tanto atacou fortemente as fontes de financiamento das entidades sindicais quanto também potencializou a precarização dos empregos ao facilitar a criação de novas modalidades de contratação, flexibilizar de forma radical os direitos trabalhistas, reduzir potencialmente os salários e diminuir drasticamente as margens de negociação.

A aplicação radical da plataforma neoliberal gerou a reação do mundo do trabalho. A resistência dos movimentos sociais e partidos de esquerda resultou em grandes mobilizações de massa e no chamamento de duas greves gerais. Mediante o crescimento das reivindicações populares, Michel Temer reage elevando o patamar autoritário da política de manu- 
tenção da "Lei e da Ordem", reprimindo violentamente as manifestações e mobilizando os militares para o controle do conflito político e para a garantia da segurança pública ${ }^{13}$. A intensificação da perspectiva repressiva se formata com a utilização do decreto presidencial que determinou a intervenção federal na área de segurança pública do estado do Rio de Janeiro, em fevereiro de 2018 (com validade até final do mesmo ano), quando a segurança pública fluminense deixou de ser coordenada pelo poder estadual e passou para a gestão federal, sob o comando de um interventor militar.

Apesar da crença dos diferentes setores do capital de que o governo Temer conseguiria alcançar a recuperação da economia e reestabelecer a acumulação - pois seguia a ortodoxia nas políticas econômicas e executava algumas (contra)reformas institucionais ditas como necessárias (trabalhista e teto de gastos) -, tais objetivos de crescimento não foram cumpridos conforme almejado. Os níveis trágicos que afetavam os indicadores sociais fermentaram uma forte crise econômica, política e institucional que gerou um cenário de altos níveis de desemprego, insegurança e instabilidade. A economia do país foi paralisada após a greve dos caminhoneiros deflagrada em maio de 2018 e que recebeu um significativo apoio popular. Junta-se a esse cenário a instabilidade política impulsionada pelo avanço das investigações da Lava Jato na sua agenda moralista de combate à corrupção, cujo objetivo inicial de atingir principalmente a esquerda que estava no poder até 2016 acabou sendo extrapolado, gerando reflexos de desmoralização política e crise de representatividade em outros partidos tradicionais com significativa participação na vida política nacional, como o PMDB (agora MDB), o PSDB e o DEM (antigo PFL).

A consequência mais deletéria dessa crise foi a emersão e o reforço dos traços mais regressistas da nossa herança histórica, sob novas roupagens. Num terreno onde o processo político foi pautado pela necessidade de restabelecimento das taxas de lucratividade através da combinação entre ortodoxia liberal e reforço das intervenções antidemocráticas e antipopulares, ganha força a crítica "antissistêmica" a partir do viés antipolítico, anticomunista e conservador-cristão. 0 terreno estava adubado e arado para a ascensão da candidatura de extrema-direita de Jair Bolsonaro, um militar reformado que se colocava como representante da "nova política" e

\footnotetext{
${ }^{13}$ Alguns exemplos dessa escalada autoritária se revelam na utilização das Forças Armadas para reprimir violentamente as manifestações do "Ocupa Brasília" (ocorrida em maio de 2017), para desobstruir as estradas e derrotar a greve dos caminhoneiros, com base na lei de "Garantia da Lei e da Ordem" (em maio de 2018) e na criminalização da greve dos petroleiros (junho de 2018).
} 
como a esperança de mudança necessária para o restabelecimento da ordem econômica, política e moral, mas representava a continuidade das práticas mais vis dos corredores da pequena política; um deputado que, durante quase trinta anos, fez parte do chamado "baixo clero" do legislativo, mudando de sigla de acordo com a conveniência, abrigando-se então num partido que mudara de nome para se desvencilhar das denúncias de corrupção - o PSL (antigo PSC).

Assentada no mantra do combate à corrupção e à ineficiência do Estado combinado com a defesa da ditadura militar e o ataque odioso ao PT e todos os setores da esquerda; impulsionando, sob a vestimenta do fundamentalismo religioso cristão, uma pauta sócio-cultural-educacional moralista, com a disseminação de práticas punitivistas, de ataques aos direitos humanos, de discursos racistas, machistas, misóginos e lgbtfóbicos; e se valendo de uma forte manipulação da informação e de um culto ao negacionismo histórico e ao desprezo a qualquer pensamento científico e progressista, a extrema-direita tomou o Planalto para aplicar o programa ultraliberal com Bolsonaro e Paulo Guedes, e elevar a um novo patamar a escalada autocrática aprofundada após o golpe de 2016 e o processo de criminalização dos movimentos sociais e populares.

Abre-se um período de reordenamento do Estado Brasileiro, com claros traços de fascistização. Uma reconfiguração do formato constitucional e institucional do Executivo - efetivado através de Emendas Constitucionais, Medidas Provisórias, Decretos, leis e outros subterfúgios administrativos - que se molda através de um aparelhamento do conjunto do Estado, "onde os órgãos de controle, de informação, de repressão e de violência estatal estão submetidos à retomada das práticas de mando ditatoriais", com um explícito projeto de aniquilação dos espaços de dissensão e de debate e de endurecimento mediante a quaisquer reivindicações de teor popular (FONTES, 2019, n/p.).

Os problemas nacionais são solucionados através da violência política. Por um lado, o radicalismo neoliberal elimina progressivamente os controles políticos sobre a movimentação do capital, destrói as políticas e programas sociais voltados para as demandas populares, retira direitos trabalhistas e aniquila as já parcas restrições à depredação do meio ambiente; por outro, os traços fascistas se revelam no reforço da tutela militar sobre o governo, na eliminação do espaço político das organizações vinculadas ao mundo do trabalho e na perspectiva repressiva baseada no reforço material, institucional e ideológico da violência policial como principal mecanismo de controle dos conflitos político e social (MACIEL, 2019). 
Os impactos da lei da liberdade econômica (13.874/19), da reforma previdenciária (EC 103/2019) e das medidas de austeridade que subfinanciaram as políticas universais de saúde, educação e assistência, implementadas durante o primeiro ano do governo Bolsonaro, foram devastadores no tocante às demandas sociais. A lei 13.874/19 (BRASIL, 2019a), que ficou apelidada de "Minirreforma trabalhista", foi o instrumento jurídico de aprofundamento - de forma mais selvagem - da destruição dos direitos efetivada pelo governo anterior (Temer). Sob a camuflagem da "desburocratização", a lei intensifica a precarização e os ataques contra a classe trabalhadora atuando em três eixos distintos: eliminação de direitos trabalhistas, redução da proteção à saúde e segurança do trabalhador e diminuição das garantias existentes aos créditos trabalhistas. A Emenda Constitucional 103/2019 (BRASIL, 2019b) desmantela todo o sistema de proteção social previsto na Constituição Federal de 1988, golpeando radicalmente os principais pilares do benefício previdenciário: dificulta o acesso à aposentadoria, aumentando a idade mínima e o tempo de contribuição; enquanto reduz os ganhos dos trabalhadores, diminuindo o valor do benefício. Os custos sociais desses desajustes não tardaram a aparecer, e no final de 2019 a precarização do trabalho já apontava níveis alarmantes: eram 12,6 milhões de pessoas desempregadas, 27,6 milhões subutilizadas e 38,4 milhões de trabalhadores na informalidade (IBGE, 2019).

Com a precariedade do trabalho, a desregularização da economia e a degradação das condições mínimas de existência da população, intensificam-se a militarização e a fascistização do Estado como forma de manutenção da "Lei e da Ordem". O chamado "pacote anticrime", formatado através de lei 13.964/19 (BRASIL, 2019c), faz alterações no Código Penal e no Código de Processo Penal que legitimam o punitivismo e transgredem frontalmente vários princípios constitucionais. A alteração do conceito de organização criminosa, a possibilidade de prisão após decisão em segunda instância, o endurecimento das penas, são algumas das medidas que esfacelam direitos fundamentais e abrem mais portas para o encarceramento em massa dos setores mais explorados e oprimidos da sociedade. Mais além, incentiva-se o uso da força letal a partir do fortalecimento do excludente de ilicitude em favor dos agentes de segurança, legitimando a "licença para matar" como método punitivo contra a classe trabalhadora ${ }^{14}$.

\footnotetext{
${ }^{14}$ Depois de ter sido retirada do Pacote Anticrime pelo GT da Câmara, o tema do excludente de ilicitude retorna em proposta encaminhada pelo presidente da república, em 21 de novembro de 2019. Nesse novo projeto de lei, foram estabelecidas novas regras aos militares das Forças Armadas e integrantes de forças de segurança em operações da Garantia da Lei e
} 
Através de decretos, portarias e projetos de lei, o presidente Bolsonaro promove, desde os primeiros dias de seu governo, medidas que visam facilitar a compra, a posse e o porte de armas. Seja no campo, onde os trabalhadores sem-terra, os povos indígenas e as comunidades quilombolas verão potencializadas contra si a violência perpetrada há décadas pelos setores ruralistas; seja na cidade, onde as populações dos bairros mais pobres e os militantes dos movimentos sociais terão amplificados os riscos de ameaças letais por partes das milícias - que vêm ampliando os seus domínios nos territórios urbanos -, estas medidas promovidas pelo Governo Bolsonaro na verdade abrem um terreno importante para impulsionar as redes paraestatais de violência que servem de suporte para consecução dos objetivos do capital.

Quando a pandemia da COVID-19 começa a assolar o país com um vírus altamente contagioso e causador de milhares de óbitos, a real faceta autocrática do Estado burguês brasileiro se revela de forma mais brutal na sua combinação entre pragmatismo da ortodoxia liberal e miserabilidade da razão neofascista.

Por um lado, o governo Bolsonaro libera $\mathrm{R} \$ 1,2$ trilhão em recursos públicos para ajuda ao sistema financeiro - com a justificativa da necessidade de apoio ao funcionamento da economia e a liberação de empréstimos às empresas -, e se utiliza do pretexto de ajuda financeira aos estados e municípios para o combate ao coronavírus para promover uma chantagem através da sanção da lei complementar 173/2020 (BRASIL, 2020): para liberar a ajuda financeira, impõe-se, como contrapartida, o sacrifício do congelamento dos salários e suspensão dos direitos dos servidores e dos investimentos nos serviços públicos, aprofundando o desmonte e a violenta desestruturação destes serviços ofertados à população em pleno momento de crise social e sanitária. Por outro, assenta-se sobre um discurso negacionista em relação à gravidade da doença, boicotando deliberadamente todas as medidas necessárias para a sua mitigação, enquanto reproduz incansavelmente o mantra da impossibilidade de disponibilização de recursos federais suficientes para o combate à pandemia devido ao fato de o país estar supostamente "quebrado". Pautado pela lógica selvagem do lucro acima

da Ordem (GLO), autorizando assassinatos sem julgamento a partir de critérios vagos e frouxos. 0 presidente Bolsonaro também cogitou criar uma GLO do campo, para apoio aos grandes proprietários, propondo, assim, "uma verdadeira legalização da jagunçada e das equipes altamente tecnológicas de, 'segurança privada' que já atuam no campo brasileiro há décadas, intimidando, assediando e assassinando pequenos trabalhadores rurais, militantes sociais, religiosos e outros que se interponham nas arbitrariedades dos grandes proprietários" (FONTES, 2019, n/p). 
das vidas, quando questionado sobre o aumento exponencial do número de óbitos decorrentes do vírus que se alastrava, o personagem grotesco que ocupa a cadeira presidencial respondia sem maiores constrangimentos: "E daí?!?"15, "Não sou coveiro!"16.

Mauro Iasi nos atenta que as feições desconcertantes assumidas pela forma atual do Estado burguês, cuja figura tosca do Presidente contribui de forma decisiva para o seu caráter burlesco, não deve desviar a atenção daquilo que é essencial nesse processo: a fúria do ultraliberalismo do Ministro da Economia Paulo Guedes “[...] em desmontar o Estado, aniquilar direitos, destruir políticas públicas, diria Weber, não são mais que meios irracionais para atingir fins racionalmente calculados" ( IASI, 2019b, n/p).

\section{Considerações finais}

A monumental derrota que se impôs sobre a classe trabalhadora nos últimos anos exige um rigoroso processo de balanço e correção de rumo. A crença na possibilidade de neutralizar o caráter de classe do Estado burguês através do aperfeiçoamento das suas instituições e do fortalecimento da "sociedade civil" estava combinada com uma expectativa duradoura no chamado "crescimento econômico com distribuição de renda". Nessas condições, o proletariado deveria abrir mão da perspectiva revolucionária em troca de um suposto compromisso das classes dominantes em respeitar as regras do jogo democrático (IASI, 2019c). Porém, continuavase vivendo em uma ordem capitalista que, como já advertia Marx desde o século XIX, passa necessariamente por crises cíclicas e periódicas. Como era esperado, o ciclo de crescimento se esgotou e estreitou as margens da política de conciliação de classes. A essa altura, já era inútil esperar qualquer guinada mais brusca no modo democrático-popular de fazer política.

A pesada sequência de derrotas das classes populares ao longo da história do Brasil alimenta a ideia de que é impossível transformar de fato esse país. Entretanto, o genocídio promovido pela burguesia e seus funcionários no governo federal em meio à pandemia da COVID-19 se soma a uma extensa lista de motivos pelos quais estamos convencidos que o impossível é continuar vivendo sob o jugo do capital. Quando acabamos de es crever essas linhas, em dezembro de 2020, mais de 190.000 brasileiros já tinham morrido por Covid-19. Para a classe trabalhadora, tomar o poder é uma questão de sobrevivência. Mas para isso é necessário reunir um vasto

\footnotetext{
${ }^{15}$ Cf. Garcia, Gomes e Viana (2020)

${ }^{16}$ Cf. CNN (2020)
} 
conjunto de condições, incluindo a exata caracterização do Estado e a compreensão da inviabilidade de qualquer estratégia política que pretenda resolver os problemas estruturais da sociedade brasileira sem destruir a supremacia burguesa.

\section{Referências}

\section{BARBOZA, D. R. A construção da democracia (vulgar) no processo da} revolução burguesa no Brasil. 2014. 566 f. Tese (Doutorado em Serviço Social). Programa de Pós-Graduação em Serviço Social, Faculdade de Serviço Social, Universidade do Estado do Rio de Janeiro, Rio de Janeiro, 2014.

BEHRING, E. R. Brasil em contra-reforma: desestruturação do Estado e perda de direitos. São Paulo: Cortez, 2003.

BOITO JR, A. Neoliberalismo e Relações de Classe no Brasil. Revista Idéias, Campinas Ano 9, v. 1, p. 13-48, 2002.

BRASIL. Portaria Normativa n. 3461. Dispõe sobre a publicação "Garantia da Lei e da Ordem”. Diário Oficial [da] República Federativa do Brasil, Poder Executivo, Brasília, DF. 20 dez. 2013. Disponível em: <https://www.defesa.gov.br/arquivos/File/doutrinamilitar/listadepublicacoesEMD/ md33_m_10_glo_1_ed2013.pdf>. Acesso em: 10 ago. 2018

Lei 13.260/2016. Regulamenta o disposto no inciso XLIII do art. 5o da Constituição Federal, disciplinando o terrorismo, tratando de disposições investigatórias e processuais e reformulando o conceito de organização terrorista; e altera as Leis n 7.960, de 21 de dezembro de 1989, e 12.850, de 2 de agosto de 2013. Diário Oficial [da] República Federativa do Brasil, Poder Executivo, Brasília, DF. 16 Mar. 2016a. Disponível em: <http://www.planalto.gov.br/ccivil_03/_Ato2015-2018/2016/Lei/ L13260.htm>. Acesso em: 12 jun. 2018.

. Constituição (1988). Emenda Constitucional no 95/2016. Altera o Ato das Disposições Constitucionais Transitórias, para instituir o Novo Regime Fiscal, e dá outras providências. Diário Oficial [da] República Federativa do Brasil, Poder Executivo, Brasília, DF. 15 dez. 2016b. Disponível em: <http://www.planalto.gov.br/ccivil_03/Constituicao/Emendas/Emc/ emc95.htm>. Acesso em: 18 nov. 2020.

. Lei no $13.467 / 2017$. Altera a Consolidação das Leis do Trabalho (CLT), aprovada pelo Decreto-Lei no 5.452, de 1ํ de maio de 1943, e as Leis 
nํㅜ 6.019, de 3 de janeiro de 1974, no 8.036, de 11 de maio de 1990, e no 8.212, de 24 de julho de 1991, a fim de adequar a legislação às novas relações de trabalho. Diário Oficial [da] República Federativa do Brasil, Poder Executivo, Brasília, DF. 14 jul. 2017. Disponível em: <http://www.normaslegais.com.br/legislacao/Lei-13467-2017.htm>. Acesso em: 24 de nov de 2020.

BRASIL. Lei no 13.874/2019. Institui a Declaração de Direitos de Liberdade Econômica. Diário Oficial [da] República Federativa do Brasil, Poder Executivo, Brasília, DF. 20 set. 2019a. Disponível em: <http://www.planalto.gov.br/ccivil_03/_ato2019-2022/2019/lei/L13874.htm>. Acesso em: 25 nov. 2020.

. Constituição (1988). Emenda Constitucional n. 103/2019. Altera o sistema de previdência social e estabelece regras de transição e disposições transitórias. Diário Oficial [da] República Federativa do Brasil, Poder Executivo, Brasília, DF. 12 nov. 2019b. Disponível em: <http://www.planalto.gov.br/ccivil_03/constituicao/emendas/emc/emc103.htm> . Acesso em: 13 nov. 2020.

Lei 13.964/2019. Aperfeiçoa a legislação penal e processual penal. Diário Oficial [da] República Federativa do Brasil, Poder Executivo, Brasília, DF. 24 Dez. 2019c. Disponível em: <http://www.planalto.gov.br/ccivil_03/_ato2019-2022/2019/lei/L13964.htm>. Acesso em: 27 nov. 2020.

. Lei complementar 173/20. Estabelece o Programa Federativo de Enfrentamento ao Coronavírus SARS-CoV-2 (Covid-19), altera a Lei Complementar no 101, de 4 de maio de 2000, e dá outras providências. Diário Oficial [da] República Federativa do Brasil, Poder Executivo, Brasília, DF. 27 Mai. 2020. Disponível em: <http://www.planalto.gov.br/ccivil_03/ leis/lcp/lcp173.htm>. Acesso em: 18 dez. 2020

BUHL, K.; KOROL, C. Criminalização dos protestos e dos movimentos sociais. São Paulo: Instituto Rosa Luxemburg Stiftung, 2008.

CARDOSO, F. H. Mãos à obra. Proposta de governo. Brasília, [ s.n.], 1994.

CARDOSO, M. L. Ideologia do desenvolvimento, Brasil: JK-JQ. Rio de Janeiro: Paz e Terra, 1978.

CASTELO, R. O Social-Liberalismo: auge e crise da supremacia burguesa na era neoliberal. São Paulo: Expressão Popular, 2013. 
CHASIN, J. O Integralismo de Plínio Salgado. São Paulo: Ciências Humanas, 1978.

CNN. "Não sou coveiro", diz Bolsonaro ao ser questionado por mortes por COVID-19. CNN. São Paulo. 20 abr. 2020. Nacional. Disponível em: <https://www.cnnbrasil.com.br/nacional/2020/04/20/nao-sou-coveirodiz-bolsonaro-ao-ser-questionado-por-mortes-por-covid-19>. Acesso em: 15 dez. 2020.

COUTINHO, C. N. Gramsci: um estudo sobre seu pensamento político. Rio de Janeiro: Campus, 1999.

Cultura e sociedade no Brasil: ensaios sobre idéias e formas, 3. ed. ampliada, Rio de Janeiro: DP\&A, 2005.

A hegemonia da pequena política. BRAGA, R.; OLIVEIRA, F. de; RIZEK, C. (orgs.). Hegemonia às avessas: economia, política e cultura na era da servidão financeira. São Paulo: Boitempo, 2010, p. 29-43.

FEDERALISTA, O. Alexander Hamilton; John Jay; James Madison / O Federalista. 2. ed. Campinas: Russel Editores, 2005.

FERNANDES, F. A revolução burguesa no Brasil. 2. ed. Rio de Janeiro: Zahar Editores, 1976.

Capitalismo dependente e classes sociais na América Latina. 3. ed. Rio de Janeiro: Ed. Zahar editores, 1981a.

Sociedade de classes e subdesenvolvimento. 4. ed. Rio de Janeiro: Zahar, 1981b.

Nova república? 2. ed. Rio de Janeiro: Zahar, 1986.

FONTES, V. O protofascismo - arranjo institucional e policialização da existência. Revista eletrônica Marxismo 21, 2019. Disponível em: <https:// marxismo21.org/wp-content/uploads/2017/05/Virg\%C3\%ADnia-Fontes-0-protofascismo-\%E2\%80\%93-arranjo-institucional-e-policializa \%C3\%A7\%C3\%A3o-da-exist\%C3\%AAncia.pdf>. Acesso em: 18 dez 2020.

GARCIA, G.; GOMES, P. H.; VIANA, H. 'E daí? Lamento. Quer que eu faça o quê?', diz Bolsonaro sobre mortes por coronavírus; 'Sou Messias, mas não faço milagre'. Globo.com. Brasília. 28 abr. 2020. G1 - Política. Disponível em: <https://g1.globo.com/politica/noticia/2020/04/28/e-dai-lamentoquer-que-eu-faca-o-que-diz-bolsonaro-sobre-mortes-por-coronavirusno-brasil.ghtml>. Acesso em: 15 dez. 2020. 
GRAMSCI, A. Cadernos do cárcere. V. 1: Introdução ao estudo da filosofia. A filosofia de Benedetto Croce. 2. ed. Trad. Carlos Nelson Coutinho. Co-ed. Luiz Sérgio Henriques e Marco Aurélio Nogueira. Rio de Janeiro: Civilização Brasileira, 2001. $6 \mathrm{v}$.

Cadernos do Cárcere. V. 3: Maquiavel. Notas sobre o Estado e a política. Trad. Carlos Nelson Coutinho. Co-ed. Luiz Sérgio Henriques e Marco Aurélio Nogueira. Rio de Janeiro: Civilização Brasileira, 2002. 6 v.

GUIMARÃES, A. P. Inflação e Monopólio no Brasil. Rio de Janeiro: Civilização Brasileira, 1963.

IAMAMOTO, M. V. Trabalho e indivíduo social: um estudo sobre a condição operária na agroindústria canavieira paulista. 2. ed. São Paulo: Cortez, 2006.

IANNI, O. Origens agrárias do Estado brasileiro. São Paulo: Brasiliense, 1984.

Pensamento social no Brasil. São Paulo: Edusc, 2004.

A ditadura do grande capital. São Paulo: Expressão Popular, 2019.

IASI, M. L. Política, Estado e ideologia na trama conjuntural. São Paulo: ICP, 2017.

Cinco Teses sobre a formação social brasileira. Serviço Social e Sociedade, São Paulo, n. 136, p. 417-438, set./dez. 2019a. Disponível em:

<http://www.scielo.br/scielo.php?pid=S0101$66282019000300417 \&$ script=sci_arttext\&tlng=pt>. Acesso em: $15 \mathrm{dez}$. 2020

O fetichismo e as formas políticas. O Estado burguês na forma burlesca. Blog da Boitempo. 2019b. Disponível em: <https://blogdaboitempo.com.br/2019/02/14/o-fetichismo-e-as-formas-politicas-o-estado-burgues-na-forma-burlesca/>. Acesso em: 20 dez. 2020

. 0 inventário da Estratégia Democrático-Popular e a busca de um caminho para a Revolução Brasileira. In: .; FIGUEIREDO, I. M.; NEVES, V. (Orgs.). A Estratégia Democrático-Popular: um inventário crítico. Marília: Lutas Anticapital, 2019c.

IBGE. Pesquisa Nacional por Amostra de Domicílios Contínua. Divulgação Especial. Medidas de Subutilização da Força de Trabalho no Brasil, 4 o trimestre de 2019. Disponível em: <https://www.ibge.gov.br/estatisticas/ 
sociais/populacao/17270-pnad-continua.html?edicao=27257\&t=publicacoes>. Acesso em: 28 nov. 2020.

JAMES, C. L. R. Os jacobinos negros. Toussaint L'Ouverture e a revolução de São domingos. São Paulo: Boitempo, 2000.

KOROL, C. Criminalização dos Movimentos Sociais na América Latina. Revista da Associação dos Docentes da UFF - Classe, Rio de Janeiro, ano 1, n. 2, p. 10-13, out/nov/dez. 2008

LEHER, R. Ideologia do desenvolvimento, pobreza e hegemonia. In: MOTA, Ana Elizabete (org.). Desenvolvimentismo e construção de hegemonia. Crescimento econômico e reprodução da desigualdade. São Paulo: Cortez, 2012, p. 7-17.

LENIN, V. I. 0 programa agrário: da Social-Democracia na primeira Revolução Russa de 1905-1907. Livraria Editora Ciências Humanas. São Paulo, 1980.

MACIEL, D. Governo Bolsonaro, ameaça fascista e luta socialista. Revista eletrônica Marxismo 21, 2019. Disponível em: <https:// marxismo21.org/wp-content/uploads/2017/05/David-Maciel-GovernoBolsonaro-amea\%C3\%A7a-fascista-e-luta-socialista.pdf $>$. Acesso em: 18 dez 2020.

MARE - MINISTÉRIO DA ADMINISTRAÇÃO E REFORMA DO ESTADO. Plano Diretor da Reforma do Estado. Brasília (DF), dezembro de 1995.

MARX, K. O Dezoito Brumário de Luís Bonaparte. 4 ed. São Paulo: Centauro, 2006.

MAZZEO, A. C. Burguesia e Capitalismo no Brasil. São Paulo: Ática, 1995. MOORE JR., B. As origens sociais da ditadura e da democracia: senhores e camponeses na construção do mundo moderno. São Paulo: Martins Fontes, 1975.

MOTA, A. E. Cultura da Crise e Seguridade Social: um estudo sobre as tendências da previdência e da assistência social brasileira nos anos 80 e 90 São Paulo: Cortez, 1995

NETTO, J. P. Ditadura e Serviço Social: uma análise do serviço social no Brasil pós-64. 8. ed. São Paulo: Cortez, 2005. 
OLIVEIRA, F. de. Hegemonia às avessas. In: ; BRAGA, R..; RIZEK, C.

(orgs.). Hegemonia às avessas: economia, política e cultura na era da servidão financeira. São Paulo: Boitempo, 2010, p. 21-27.

PAULANI, L. M. Capitalismo financeiro, estado de emergência econômico e hegemonia às avessas no Brasil. In: BRAGA, Ruy Braga; OLIVEIRA, Francisco de; RIZEK, Cibele (org). Hegemonia às avessas: economia, política e cultura na era da servidão financeira. São Paulo: Boitempo, 2010, p. 109136.

PRADO JR., C. História Econômica do Brasil. São Paulo: Brasiliense, 1963. Formação do Brasil Contemporâneo: colônia. São Paulo: Brasiliense, Publifolha, 2000.

Evolução política do Brasil: e outros ensaios. São Paulo: Companhia das Letras, 2012.

SCHWARZ, R. Ao vencedor, as batatas. Forma literária e processo social nos inícios do romance brasileiro. São Paulo: Editora 34, 2000.

SODRÉ, N. W. História da Burguesia Brasileira. Rio de Janeiro: Civilização Brasileira, 1964.

VIA CAMPESINA BRASIL. A Ofensiva da Direita Para Criminalizar os Movimentos Sociais no Brasil. São Paulo, 2010. Disponível em: <https:// www.alainet.org/images/Criminalizacion_Brasil_portugues.pdf>. Acesso em: 28 nov. 2020

WEFFORT, F. 0 populismo na vida política brasileira. 5. ed. São Paulo: Paz e Terra, 2003 